\title{
Electrocardiogram Group Identifier
}

National Cancer Institute

\section{Source}

National Cancer Institute. Electrocardiogram Group Identifier. NCI Thesaurus. Code C83260.

A character or string that represents a electrocardiogram group. 